УДК 338.483.11

\title{
PILGRIMAGE AND RELIGIOUS TOURISM ON THE WAY OF ST. JAMES - THE FIRST EUROPEAN CULTURAL ROUTE
}

\author{
F. Mróz*, L. Mróz** \\ *Pedagogical University of Krakow - Institute of Geography \\ The Podhale State Higher Vocational School in Nowy Targ \\ **Jagiellonian University in Krakow - Institute of Geography and Spatial \\ Management
}

\begin{abstract}
Since last two decades we notice an intensive growth of the pilgrimage movement along the Way os St. James. This route connecting furthests places in Europe and ending in Santiago de Compostela is based on a medieval transportation route called The Royal Route - Via Regia. The route exists for over 1000 years and is constantly developed thanks to actions taken by the authorities of the Catholic Church, governments and non-government organizations, as well as numerous enthusiastics of the Way of St. James.

Keywords: The Way of St. James - Camino de Santiago, the route Via Regia, European Cultural Routes, pilgrimage, religious tourism, cultural tourism.
\end{abstract}

Since last two decades we notice an intensive growth of the pilgrimage movement along the Way os St. James. This route connecting furthests places in Europe and ending in Santiago de Compostela is based on a medieval transportation route called The Royal Route - Via Regia. The route exists for over 1000 years and is constantly developed thanks to actions taken by the authorities of the Catholic Church, governments and nongovernment organizations, as well as numerous enthusiastics of the Way of St. James.

Since 1987, when the Council of Europe declared the pilgrimage route to Santiago de Compostela the first European Cultural Route we notice re-creation of former pilgrimage routes accros all european countries. The Way of St. James, marked on its whole lenght with the motif of the scallop shell, leads from Poland, Germany, Austria, Switzerland, France, Italy and ends in the Cathedral of Santiago de Compostela in Spain at the tomb of St. James the Apostle. It is estimated that over 5 million people a year visit the sanctuary of St. James in Santiago de Compostela.

Since the early '80s the Pilgrims' Office of Archdiocese of Santiago de Compostela analyze the pilgrimage movement to the tomb of St. James. Basing on its research we should pointed out that vast majority of pilgrims who received the "Compostela" in 2010 (document confirming the pilgrimage to Santiago de Compostela) came on foot. There are also pilgrims coming to the tomb of the first marthyr by bike, on horseback or even in a wheelchair. Although the Spanish are still the largest group of pilgrims, the Pilgrims' Office noticed a significant growth of foreign pilgrims. People undertake the pilgrimage to Santiago de Compostela for various reasons: pure religious, cultural-religious or cultural motives.

Currently, there is more than $3200 \mathrm{~km}$ of Camino de Santiago in Poland and they are

(C) Mróz F., Mróz Ł., 2013 
divided into 16 sections. Polish part of the route meets Via Regia in Germany in Görlitz. The opening of the Way of St. James Via Regia from Korczowa (located on PolishUkrainian border) - hopefully will become a strong impulse to develop religious tourism on the medieval route to Kiev.

\section{Introduction}

The Way of St. James (Spanish: El Camino de Santiago, German: Jakobsweg) is one of the most important Christian pilgrimage routes and the first European Cultural Route. Existing for over 1000 years route, in the last two decades experience a tremendous growth. The Way of St. James is a route in every respect unique, defined as the most beautiful route in the world and the way of life. Currently, the Camino de Santiago runs through nearly the whole Europe and ends in the Cathedral of Santiago de Compostela. According to the tradition, the relics of St. James - the first martyr among the Apostles, are kept here. Exactly on this pilgrimage route - as Johan Wolfgang von Goethe wrote - European consciousness was born [14].

One of the sections of Camino de Santiago, that since the Middle Ages connected Kiev and the Iberian Peninsula, ending in Santiago de Compostela, was so-called The Royal Route - Via Regia. Thereby, it was one of the markers of culture and religion in this region. Also today, in the united Europe, it is a significant factor of the development of particular regions, as well as a place which attracts pilgrims and tourists from abroad. As well as on the medieval pilgrimage route, on The Way of St. James, meet pilgrims from the whole continent.

2. Religious tourism and pilgrimage.

Tourism is an interdisciplinary phenomenon in a wide range affecting human life. A specific type of tourism is cultural tourism. It is considered to be the oldest form of tourism. In a broad concept of culture, cultural tourism is defined as: "All these group and individual trips of a touristic character, where participants meet objects, events, and other qualities of high culture or popular culture, or increase their knowledge of the world organized by human (the world we live in) is an essential part of the journey or a conclusive argument for the individual decision to initiating or taking part in it" [12].

Cultural tourism is considered as one of the most important segments of tourism in the world, especially in Europe. This form of tourism is based on learning of culture in a broad sense and relations with local communities. It is estimated that $70 \%$ of revenue in tourism industry comes from the cultural tourism [9].

Religious tourism belongs to cultural tourism and is defined by A. Jackowski as a journey taken due to religious or religious-cognitive reasons. In this migration, the place of worship is usually not a destination, but is just a part of the itinerary. Despite the fact, that when visiting the shrine tourists are participating the acts of worship, they still bring visiting objects of religious culture to the fore [4].

Pilgrimages are the specific type of religious tourism. They have very clear religious motives. The aim of the journey is to reach the holy place (sanctuary). The whole travel and stay at the place of worship is dedicated to the prayer, participation in church services, individual moments with God, personal reflections/thought, contemplation, penance and other forms of devotion. In contrast to the other forms of travel within the religious tourism - every pilgrimage is at the same time one of the most important religious practice, which 
has purely religious motives. Especially walking pilgrimages play significant role [7].

Analyzing religious tourism on the Way of St. James, we should first clearly pointed out that Camino de Santiago is mainly a pilgrimage route. The route, which, as already mentioned, since last two decades is experiencing a revival. The vast majority of people participating those tours, or walking and horse riding trips to Santiago de Compostela are making those journeys mainly due to religious or religious-cognitive reasons. The nature of the pilgimages to Santiago de Compostela is specific, because we usually meet single pilgrims, as well as groups of several or dozen travelers. The Way of St. James is often called the way of life - the way, on which many people are looking for answers to questions on faith and life. That is why on Camino de Santiago we can also meet atheists, those looking for faith - people of different races, religions, people of all ages and education. There is a lot of people who make their way to Santiago de Compostela only for cognitive reasons. Despite the cultural and religious differences and language barriers, "caminowicze" strike up great friendships. You can often hear the opinion that you start the journey on Camino as "a tourist" and finish as "a pilgrim".

The attribute of every pilgrim going to Santiago de Compostela is a scallop shell attached to a backpack, bicycle saddle bags or worn around the neck. It can be also stuck to the walking stick onto which a gourd of water is attached. A scallop shell is also used to mark St. James' Way.

3. Pilgrimage on The Way of St. James - history

The origin of the pilgrimage movement to the tomb of St. James the Apostle in Santiago de Compostela is dated back to the 9th century. Its growth falls on between 12th and 14th century. The discovery of the marble sarcophagus with the remains of St. James the Apostle in 813, caused the development of the cult of St. James and the pilgrimage movement on this route. According to the legend, that was accomplished by hermit Pelayo (Pelagius), who one night saw a "rain" of stars falling on the hill called Liberum Donum concealing the relics of St. James. Around the tomb of St. James a settlement called Campus Stellae - "Field of the star", was founded [6]. The first cathedral was built in 9th century on the spot of Apostle's grave. Another temple was built from 1075 to 1122. The present cathedral is the third temple in Santiago [15]. In 900, Santiago de Compostela become the seat of bishopric. During this period, the cult of St. James was already strongly developed outside Spain. The kings, knights, merchants, priests, peasants and beggars made their pilgrimages to the tomb of the first martyr among the Apostles. The penitents were a large group among the pilgrims.

The development of the shrine of St. James the Apostle in Santiago de Compostela was also influenced by the relevant papal privileges. In 1122, Pope Callixtus II gave the shrine of St. James in Compostela the right to celebrate the Holy Years [16]. In 1179, in the apostolic bull Regis Aeterni, Pope Alexander III made this privilege perpetual. In 1478, Pope Sixtus IV, declared a pilgrimage to the tomb of St. James in Santiago de Compostela to be equivalent to a pilgrimage to Jerusalem [1].

In the 13th century, the shrine of Santiago de Compostela, by the papal Act was considered as one of the three most important centers of pilgrimage in Christian world (along with Jerusalem and Rome) [1]. In the 12th and 13th centuries on European routes to Santiago de Compostela pilgrimage over 500 thousand people a year. Pilgrims-penitent, 
who were often scourging themselves at the time of the pilgrimage, were a significant group among the pilgrims. Undertaking such pilgrimages in the Middle Ages was also a form of punishment for the crime of murder [7].

In 1589, the relics of St. James were hidden as a result of the threat of invasion of the English corsair, Francis Drake, on Santiago de Compostela. It also contributed to the slow recession of pilgrimage routes to Santiago de Compostela. Over 16th and 17th centuries, when a wave of religious battles, epidemics and natural disasters came through Europe, the rank of Camino de Santiago decreased. In the following centuries the French Revolution and the Napoleonic Wars hampered pilgrimage movement. The Ways of St. James have become gradually forgotten.

Over the centuries, as the result of finding the relics of St. James, what has been confirmed by a special bull of Pope Leo XIII in 1884, came the revival of the pilgrimage movement. In modern times, another growth of pilgrimage movement went through various stages.

The "re-discovery" of Compostela and the revival of pilgrimage movement on Camino de Santiago, has began after the first pilgrimage of Blessed Pope John Paul II in Santiago de Compostela (9th November 1982) [5]. "European Act", delivered by the Pope during his visit, was an invitation to liven up the Christian tradition of pilgrimage to the tomb of St. James. The revival of pilgrimage movement and development of religious tourism to Santiago de Compostela was also the result of actions taken by the authorities of the Catholic Church in Spain and Spanish governments, as well as an autonomous regions through which Camino Francés - The French Way goes.

In 1987, the Council of Europe approved the pilgrimage route to Santiago de Compostela the first European Cultural Route and encouraged the authorities of the regions to recreate former pilgrimage routes. Initially, in Spain, and in the following years in France, Germany, Italy, Austria and Switzerland, signposts with a motif of a scallop shell of St. James appeared. In 1989 Pope John Paul II again arrived in Santiago de Compostela to meet a group of 400 thousand young people taking part in the 4th World Youth Day. This world youth meeting at the tomb of St. James the Apostle has left an indelible mark on the history of the pilgrimage to Compostela [2].

In 1993 the pilgrimage route to Santiago de Compostela in Spain, and in 1998 the route in France, were entered by UNESCO on its World Cultural Heritage List. The year 1993 was declared by Council of Europe to be the Year of the Way of St. James. All these events caused that since last thirty years we observe the revival of the pilgrimage on the Way of St. James.

4. Pilgrimage and religious tourism on the Way of St. James in 1980-2012.

Nowadays, the sanctuarynof St. James in Santiago de Compostela is rated as one of the most important Christian pilgrimage centers in the world. It is estimated that more than 5 million people a year arrives to the tomb of St. James in Compostela [13].

The analysis of pilgrimage movement to the tomb of St. James in Compostela was based on data collected by the Pilgrims' Office of Archdiocese of Santiago de Compostela (Oficina del Peregrino de Santiago de Compostela) since 1980. Since 2004, the Office gathers detailed statistics on people who came to Santiago de Compostela on foot, on horseback, by bike or in a wheelchair and received the "Compostela" (document recording the pilgrimage to the tomb of St. James - the last $100 \mathrm{~km}$ of Camino de Santiago made on 
foot, on horseback or in a wheelchair, or $200 \mathrm{~km}$ by bicycle).

Basing on the data of Pilgrims' Office of Archdiocese of Santiago de Compostela we should pointed out that since the mid 80's a steady growth in number of pilgrimage groups coming to the tomb of St. James has been noticed. The first clear revival of the pilgrimage movement was registered back in 1982 (1869 people), which was related to the Holy Year of St. James celebrated in Santiago de Compostela and already mentioned the first pilgrimage of Blessed John Paul II to the tomb of St. James. In 1985-1990 the number of registered pilgrims in Santiago de Compostela has increased more than seven times (in 1985 - 690 pilgrims were registered, while in 1990 - 4918 people) [27]. Noticeable in 1989, 1993, 1999, 2004 and 2010 pilgrimage movement intensity is also associated with the Holy Year of St. James, celebrated in Santiago de Compostea. The first major inflow of pilgrims has already been reported in 1989 (5,760 people), when 4th World Youth Day, attended by blessed John Paul II, was organized in Santiago de Compostela. Another rapid pilgrimage movement has been registered in 1993 during 116th Holy Year celebration. 99.4 thousand people came to Compostela that year. A record number of pilgrims in modern history, who visited the tomb of St. James was recorded in 2010 - it was 272,135 people [29]. In 2011, the Pilgrims' Office registered 183,366 pilgrims. 153, $065(83.5 \%)$ people of this group came to Santiago de Compostela on foot, 29,949 (16.3\%) people arrived by bicycle, 341 people arrived on horseback, while 11 pilgrims in a wheelchair [30]. By December 2012, the number of pilgrims who received the "Compostela" exceeded 190 thousand (see Figure 1). It should be noted that each year, the number of pilgrims who undertake a pilgrimage right on their doorstep, traveling even up to several thousand kilometers.

Along with the growth of pilgrimage movement to Santiago de Compostela we notice its increasing internationalization. Taking into consideration the statistics of the Pilgrims' Office of Archdiocese of Santiago de Compostela from years 2004-2011, we can see a significant decrease of role of the Spanish in general number of those who travel to Santiago de Compostela. In 2004 the Spanish accounts for 76,22\% of the general number of pilgrims (137163 people), whereas in 2011 it was 53,35\% (97822 people) [30].

The largest group (after the Spanish) of people traveling to the tomb of St. James in Santiago de Compostela are the Germans, the Italians, the Portuguese, the French and the Americans. In 2011 - $16596(9 \%)$ of the Germans, $12183(6,6 \%)$ of the Italian people, 8649 $(4,7 \%)$ of the Portuguese, $8166(4,4 \%)$ of the French and 3726 residents of United States received the „Compostela” [29].

Analysing the nationality structure of those who travel to Santiago de Compostela in recent years, it is worth noting the increase in the number of Poles in the total number of pilgrims. In 2010 - in the Holy Year of St. James, 2040 polish people $(0,75 \%)$ received so-called "Compostela" [30]. In 2011 the number of polish pilgrims in Santiago de Compostela was slightly lower (in comparison to 2010) - achieving the level of 1820 people. Nevertheless, the number of the Poles in the overall number of pilgrims went up to almost $1 \%$ of the total number $(0,99 \%)$ [30]. It is worth noting that in 2012 , only in the holiday season from July to August, 1070 Polish people received the "Compostela" which is about $4 \%$ of all foreigners (polish pilgrims ranked the 5thplace among pilgrims from abroad) [28]. Figures mentioned above are in some sense the fulfillment of the words that Metropolitan of Santiago de Compostela, Archbishop Julián Barrio Barrio, declared 
on 1stJuly 2010 on Monte do Gozo, during his meeting with Polish pilgrims. "A month ago I have been on a pilgrimage in Poland from which I kept beautiful memories. When I returned to Santiago, I said that Poland will be the source of the ceaseless flow of pilgrims traveling to the tomb of St. James" [3].

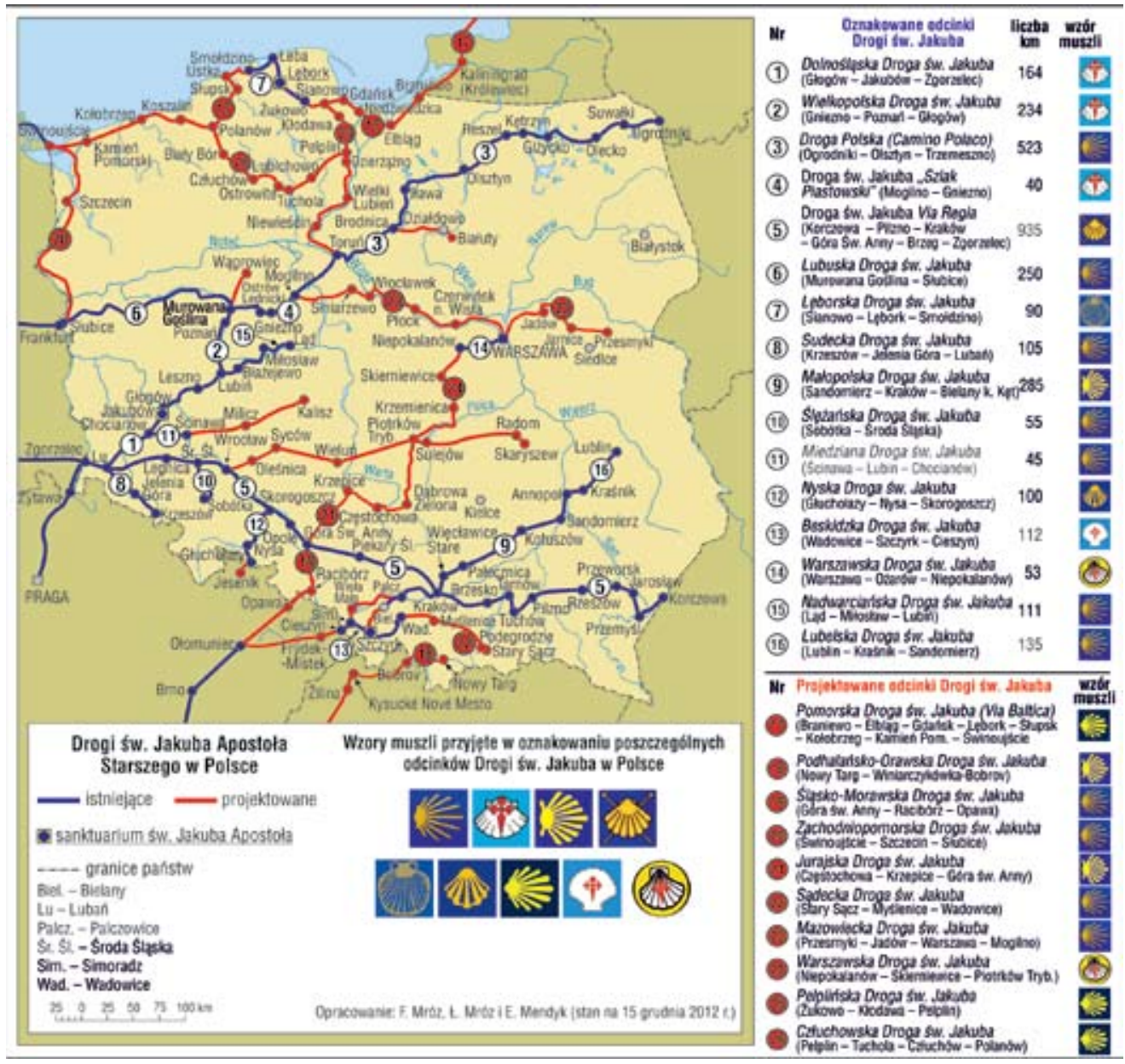

Fig. 1. Dear St. James in Poland

A significant increase in the number of pilgrims on the pilgrimage route leading to Santiago de Compostela, thereby, popularisation and internationalization of pilgrimage movement, caused a significant change of the motives for undertaking the trouble of traveling on Camino.

Currently, there is a noticeable downgrade in religious motives which are of vital importance in making the journey to Santiago de Compostela. Among the options for selecting the motives, that determined undertaking a journey to Compostela - those who received the "Compostela", beyond the religious motive, could also mark religious-cultural theme (non-religious). If in 1989 , up to $83.5 \%$ of the total pilgrim pointed the religious 
motive, $12.67 \%$ religious-cultural motive, and $1.5 \%$ non-religious motive, in 2010 , the change in the leading motives of traveling to Compostela was already clearly visible. Respectively: religious motive indicated $43.07 \%$, religious-cultural $50.8 \%$, cultural motive declared $6.14 \%$ (see Figure 2). It should be pointed out that by 2004 the recorded vast majority of those who came to the tomb of St. James arrived only for religious reasons. Nevertheless, in 2005 the percentage share of pilgrims was down to about $37.7 \%$. The intensity of people receiving the "Compostela" for purely religious motives is still being observed in the Holy Years of St. James - in 2010 it was 54.8\%.

5. The Way of St. James Via Regia - genesis and development conditions in Germany, Poland and Ukraine.

Germany was one of the first countries not bordering directly on Spain, who attempted to recreate and re-mark the Camino de Santiago. This work has been initiated by the Protestant pastor Paul Geißengörfer in 1992 [18]. The first recreated Way of St. James in Germany was, opened in 1995, the route of St. James leading from Nuremberg to Rothenburg. The following years this route has been extended from the Czech border in Tillyschanz village. In Czech Republic, on sector Prague-Rothenburg, this route is called The Northern Way of St. James.

According to the research and analysis of particular sectors of St. James routes it has been established that in the Federal Republic of Germany exists about $11500 \mathrm{~km}$ marked sections of the Way of St. James - Jakobsweg, with a total number of 30 main routes of Camino de Santiago.

Establishment of routes of St. James in eastern Germany was undoubtedly an impulse to mark the first sector of the Way of St. James in Poland. An example would be the established of Ecumenical Pilgrimage Route Via Regia from Görlitz to Vacha in 2003. That was the impulse for creation of Dolnoslaska Way of St. James (2005) and St. James Way Via Regia (on the section Brzeg - Zgorzelec in 2006). Similarly, the Ways of St. James in the Province of Brandenburg referring to the main route from Gniezno to Magdeburg influenced marking the Lubelska Way of St. James in 2008 [17]. In 2003, the European network of Camino de Santiago reached the German-Polish border in Görlitz / Zgorzelec. The next year, the Poles who pilgrimage to the tomb of St. James began to work on the demarcation Polish sections of the Way of St. James. The first section, which has been recreated and solemnly opened on 24th July 2005 was Dolnoslaska Way of St. James, leading from Jakubów (the medieval centre of cult of St. James - now the sanctuary of St. James) to Zgorzelec, where it connects with the German route of St. James (the Ecumenical Pilgrimage Route- Ökumenischer Pilgerweg). Thus Poland joined the countries in which sections of the Way of St. James has been created. Currently on territory of Poland, there are the following sections of Camino de Santiago: 1. Lower Silesian/Dolnoslaska Way of St. James, 2. Greater Polish/Wielkopolska Way of St. James, 3. The Polish Route (Camino Polaco), 4. The Way of St. James "Piastowski Way", 5. The Way of St. James "Via Regia" (Korczowa - Zgorzelec), 6. Lubuska Way of St. James, 7. Leborska Way of St. James, 8. Sudecka Way of St. James, 9. Lesser Polish/Malopolska Way of St. James, 10. Slezanska Way of St. James, 11. Miedziana Way of St. James, 12. Nyska Way of St. James, 13. Beskidzka Way of St. James, 14. Lubelska Way of St. James, 15. Warszawska Way of St. James, 16. Nadwarcianska Way of St. James (see picture 3). 


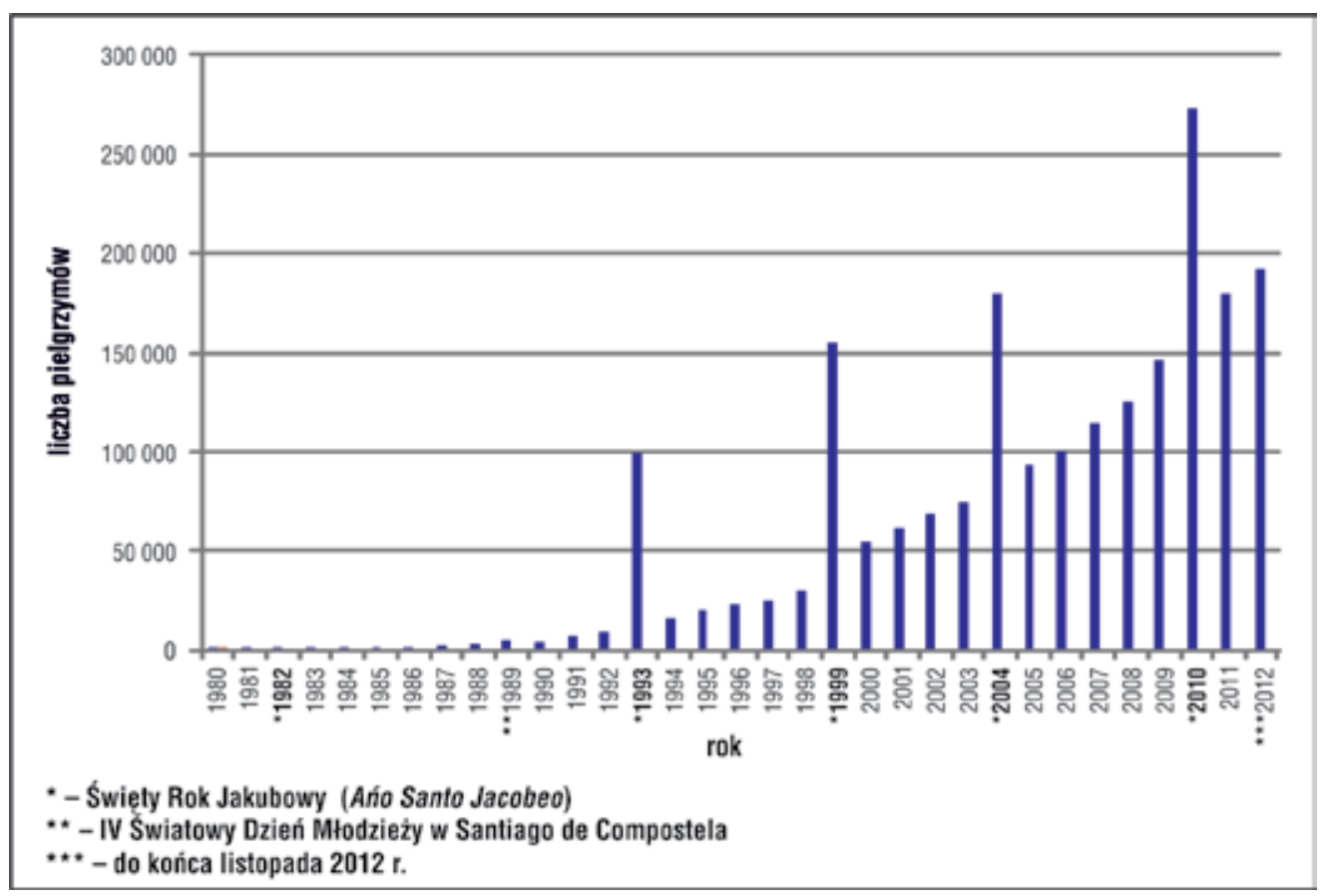

Picture 3. Number of pilgrims 1980-2011

It is worth noting that in 2005-2012 thanks to the involvement of the Church, local authorities and numerous enthusiastics of the Way of St. James, more than $3200 \mathrm{~km}$ of the sectors with the motive of St. James' shell have been maked and opened in Poland. Even today, we can say that Polish sections of the Way of St. James permanently entered the European network of Camino de Santiago.

It should be noted that in many Polish parishes of St. James, fraternities and associations of St. James and among the worshipers of St. James, new initiatives related to the cult of the Apostle and creation of new sections of St. James' Way has arisen. Currently 9 new routes are already in progress - i.a. Podhalańsko-Orawska Way St. James and another sectors of Mazowiecka Way St. James and Beskidzka Way of St. James. Each year, the number of people, who individually or in small groups decide to undertake the pilgrimage on polish "route of the Shell", is rising. We anticipate new initiatives of walking trips and bike rides on the Way of St. James, initiated by school children, students and scouts. Visits of foreign pilgrims may become a chance for development and possibility for the Way of St. James in Poland to be included in the European network of St. James' Ways.

One of the most important sections of Camino de Santiago in Polish and Germany is the Way St. James "Via Regia". It was running along the historic, medieval trail, which was in the Middle Ages one of the most important transportation routes in Central Europe. For the first time this former trade route was mentioned in 1252, under the name of "Strata Regia" - the Royal Route in documents of Margrave of Meissen, Henry III [25]. The route was called the Royal Route, or the High Route - Via Regia, due to the fact, that running through the territory 
of a given country was a subject to the king and specific local rights. Historically, "Via Regia", as a trade route ran from Russia to the Iberian Peninsula, linking far-flung regions, cultures, religions and traditions. Following this trail you could safely move from Kiev to Santiago de Compostela. Not only the traders and the armies, but also pilgrims going to the tomb of St. James the Apostle in Santiago de Compostela were moving along this route. Via Regia was a interregional way, that encouraged the development of trade relations between European countries and caused formation of new urban centers [21]. On its route, cities such as Cologne, Frankfurt, Leipzig, Wroclaw, Krakow and Lviv has been established. In 13th and 14th century, new cities were regularly created. They were local nodal points located along the route, where you could exchange goods, obtain accommodation and service for the travelers. The Royal Route lost its importance only in the 19th century, when the railway began to develop rapidly.

Currently, Via Regia is a very important communication corridor connecting East and West. Many projects of the European character are now being implemented around Via Regia. Within the project of the European Union Via Regia Plus marking and extension of transportation routes along the former Royal Route and the development of the European Development Corridor III ED-C has been introduced. This venture, of the total cost of EUR 3200000 Euro [22], was an initiative of the regional and local partners from Poland, Ukraine, Slovakia and the Czech Republic.

It is worth stressing, that in 2005, the Council of Europe recognized Via Regia as an important cultural and tourist route and qualified it as the European Cultural Routes [33].

In Germany, the Ecumenical Pilgrimage Route - Via Regia, was opened in 2003. It is the only one Route in Germany that offers pilgrims many pilgrimage hostels organized by parishes, monasteries and at private houses on its full lenght.

Historical sources indicate, that one of the branches of Via Regia led via Frankfurt am Main, Mainz, Trier and Metz to Paris. Today, the route from Vacha via Fulda to Frankfurt and another one from Trier via Luxembourg and Reims to Paris are marked as the Way of St. James and the extension of the Ecumenical Pilgrimage Route.

Via Regia in Germany starts in Görlitz and goes through Leipzig, Freyburg, Erfurt Wisenach leads to Vacha. In 2010, a section from Mainz to Trier was opened - this Route is also known as Via Regia. The route Via Regia has about $470 \mathrm{~km}$ and was opened in 2003. The route is appropriately adjusted for cyclists [26]. From Eisenach, you can continue the pilgrimage from Magdeburg to Cologne along the, so-called, Way of St. Elisabeth (Elisabethpfad), which is $220 \mathrm{~km}$ long part of the Way St. James from Vacha to Würzburg (Jakobsweg Vacha - Fulda - Würzburg). This part of the route between Fulda and Schweinfurt is called Rhönjacobsweg and is marked with a shell with blue outline [19]. The next section of the Way St. James runs from Fulda via Mainz, Frankfurt to Trier (Jacobsweg Fulda - Meinz - Trier). It is about 322 $\mathrm{km}$ long. The route was based on the historical route that led from Leipzig to Frankfurt am Main. The route from Fulda to Frankfurt is also a historical section of Via Regia and was opened on 8th May 2010 [24].

The Way of St. Elizabeth (Elisabethpfad) is an ecumenical pilgrimage route, that consists of three variants, leading to the sanctuary of St. Elizabeth in Marburg and connecting the sanctuary of the Three Kings in Cologne. The route connects places related to the person and activities of St. Elizabeth of Thuringia, called Elizabeth of Hungary [20]. The first route 
was opened in 1996 and leads from Watzlar to Marburg. It is not marked with a sscallop hell, however, in the opposite direction is considered to be Camino de Santiago connecting Lahn and Mosel-Camino towards Trier. The next two St. Elizabeth's Ways from Eisenach to Marburg and from Cologne to Marburg were opened in 2007. They are both marked, as Elisabethpfad and in the opposite direction as Jakobsweg. The route has about $400 \mathrm{~km}$ : Eisenach - Marburg (about $180 \mathrm{~km}$ ), Marburg - Cologne (about $170 \mathrm{~km}$ ), Marburg to Wetzlar (about $50 \mathrm{~km}$ ) [23].

The Way of St. James running along the former High Route was one of the first routes of St. James recreated in Poland. The initiator of this route was the "Franciscan Village Foundation". The first section of Via Regia, is about $240 \mathrm{~km}$ long and was opened on 6 October 2006 in Wroclaw, and goes through: Brzeg - Olawa - Wroclaw - Sroda S1. - Prochowice - Legnica / Legnica Pole - Zlotoryja - Lwowek Sl. - Luban - Zgorzelec. Since Via Regia has merged with the mentioned Ecumenical Pilgrimage Route - "Ökumenischer Pilgerweg" on the Old Town Bridge in Zgorzelec / Görlitz it has joined the network of European routes with the motive of the scallop shell. The opening ceremony of the Way St. James Via Regia was attended by i.a. Minister of Culture and National Heritage Kazimierz Michał Ujazdowski, members of the Fraternity of St. James in Jakubow, residents of Wroclaw and pilgrims from various parts of Poland. Another activities of "Franciscan Village Foundation" led to the inclusion of the next section of Way of St. James Via Regia: Mount St. Anna - Opole - Skorogoszcz - Brzeg. The opening of this segment of the route took place on 15th September 2008 [11].

The beginnings of the creation of the Way of St. James Via Regia in Malopolska Province and Podkarpackie Province date back to 2007, when a meeting of those who pilgrim to Santiago de Compostela took place in Cracow. At the same time, they worked towards the reconstruction of another section that runs through the south-eastern Poland - Malopolska Way St. James from Sandomierz to Krakow. As a result of the arrangements and the work on marking the course of Via Regia in south-eastern Poland, from May to September 2009, the parish of BVM Mother of the Church and parish of St. James in Brzesko with the support of the Marshal's Office in Krakow, delineated and marked another section of the route: Tuchow - Tarnow - Brzesko - Krakow. The following months the section Pilzno - Tuchow has been marked. The opening of the section of Via Regia in Malopolskie Region Pilzno - Krakow took place in Brzesko on 24th July 2010.

On 8th August 2010, in the Dąbrowa Basin (Zagłębie Dąbrowskie) at Mount St. Dorothy in Bedzin, another section of the Way of St. James Via Regia was opened. That leads from Krakow to Mount St. Anne. As a result, the only one missing polish section of Via Regia was the route that runs in Podkarpacie Region from Korczowa to Pilzno [10].

An intensive work on the demarcation and marking the Way of St. James in Podkarpacie Region has began just in 2011. Extremely important fact, that has affected the successful follow-on to accomplish the demarcation of Via Regia in Podkarpackie Province, was an agreement on laying out the route in the Archdiocese of Przemysl. This decision was made by the Metropolitan Archbishop. Jozef Michalik - President of the Polish Episcopal Conference and Bishop Kazimierz Gorny - the Ordinary of the Diocese of Rzeszow. The project of marking the route was supported by government funds provided by the Marshal's Office in Rzeszow. That allowed the route to be marked by a dedicated person from PTTK Organization, issue guidebooks, promotional leaflets and information boards at specific 
historic buildings located on the route. The direct beneficiary of the project supported by the Marshal's Office in Rzeszów was ProCarpathia Association based in Rzeszów, in cooperation with the Association "Friends of the Way of St. James in Poland". A non-governmental youth organization - Podkarpacka Organization of The Scouting Association of the Republic of Poland (ZHR) also got involved into the idea of setting the Way of St. James Via Regia in Podkarpacie Region. At the later stages of the work on the Way of St. James Via Regia scouts undertook to maintain these marking, as well as animation of the pilgrimage movement in cooperation with the Church and social authorities. Currently, scouts from Podkarpacka Organization of ZHR coordinate further works related to the promotion and take care of the route.

In November 2011, the activities on setting and marking the last section of the Way of St. James Via Regia from Korczowa via Przemysl, Jaroslaw, Przeworsk, Rzeszow to Pilzno has been completed. Thereby, the route was entered into a nationwide network of The Way of St. James in Poland. It is considered that on 5thJanuary 2012, the route was opened by the Marshal's Office. The opening of the Way of St. James Via Regia from Korczowa - the town located near the Ukrainian border - can be considered as the impulse for developing the religious tourism on this medieval route on the territory of Ukraine.

Currently, relatively small number of the Ukrainians pilgrimage to Santiago de Compostela (in 2010 - it was 65 pilgrims, while in 2011, only 48 people). Nevertheless, the promotion of route in Ukraine may vivify the pilgrimage movement from Ukraine.

In 2011, members of the Fraternity of St. James in Wieclawice Stare made contact with some people from Lviv, who are interested in setting the Way of St. James in Ukraine. We hope, that our cooperation will allow us to start works on marking the Way of St. James along the historical - medieval High Route - from Kiev to the Polish-Ukrainian border in Korczowa and Medyka. It will be undoubtedly a further impulse to the international integration of many local communities concentrated on the idea of the pilgrimage on Camino de Santiago. Probably the Way of St. James, like in the Middle Ages, will become a medium of European integration. Just the route marking and the performance of the route of St.James on the territory of Ukraine may become a chance for the development of religious and cultural tourism in this part of Europe.

\section{Summary}

The Way of St. James - Camino de Santiago is the longest and the most famous pilgrimage and cultural route in Europe. This route exists for over 1000 years and in the last two decades experienced another renascence. Currently, it is estimated that over 5 million people a year visit the sanctuary of St. James in Santiago de Compostela. The majority of pilgrims traveling to Santiago de Compostela comes (apart from Spain) from Germany, Italy and Portugal. Camino de Santiago also significantly affects the development of religious and cultural tourism in the areas through which it runs. There are additional initiatives in various parts of Europe, which aim for development of the cult of St. James, as well as the creation of new sections of Camino de Santiago. It is worth noting, that since the early 90s till July 2012, nearly 15 thousand kilometers of St. James' routes were prepared and marked in Poland and Germany. The next year another sections of the Way of St. James are scheduled to open. Like ages ago, people who wish to renew and strengthen their faith, and in an expressive way confirm the spiritual origins of the Old World, will travel to the tomb of St. James the Apostle 
in Santiago de Compostela. Reconstruction of the Way of St. James, along the medieval route Via Regia from Kiev, gives development prospects for the religious and cultural tourism in Ukraine.

\section{LIST OF REFERENCES}

1. Adamczyk S., Zasługi papieża Kaliksta II (1119-1124) w szerzeniu kultu św. Jakuba Apostoła, [w:] Jackowski A., Mróz F. i Hodorowicz I. (red.), Wpływ Świętego Roku Jakubowego na rozwój kultu i Drogi św. Jakuba, Wydawnictwo „Czuwajmy”, Kraków 2011, s. 53-54.

2. Barrio Barrio J., Europa widziana z Santiago, [w:] w:] JackowskiA., MrózF., (red.), »Akt Europejski« bł. Jana Pawła II, a renesans Drogiśw. Jakuba w Europie, Wydawnictwo „Czuwajmy”, Kraków2012, s. 14-15.

3.HodorowiczI.,MrózF., Geograficznyzasięgkultuśw.JakubawPolscenaprzykładziewezwańkościołów ikaplic pod wezwaniem Apostoła, [w:] JackowskiA., MrózF., Hodorowicz I.(red.), Kultśw. JakubaApostoła na szlakach pielgrzymkowych do Santiago de Compostela, Wydawnictwo „Czuwajmy”, Kraków 2010, s. 63.

4. Jackowski A., 1991, Pielgrzymki i turystyka religijna w Polsce, Warszawa, s. 8; Jackowski A., Święta przestrzeń świata. Podstawy geografii religii, Wydawnictwo Uniwersytetu Jagiellońskiego, Kraków, 2003, s. 123-124.

5. Jackowski A., Sołjan I. (red.), Szlaki pielgrzymkowe Europy. Leksykon, Wydawnictwo Znak, Kraków 2000, s. 19; H. J. Muszyński, Przedmowa, [w:] A. M. Wyrwa (red.), Camino de Santiago. Szkice historyczne do peregrynacji i dziejów kultu św. Jakuba Apostoła Większego, Lednica 2010, s. 8; A.M. Wyrwa, Święty Jakub Apostoł. Malakologiczne i historyczne ślady peregrynacji zziem polskich do Santiago de Compostela, Lednica - Poznań 2009; F. Mróz, Ł. Mróz, Sukcesy i wyzwania związane z rozwojem kultu i Drogi św. Jakuba w Polsce, [w:] Jackowski A., Mróz F., Hodorowicz I. (red.), Wpływ Świętego Roku Jakubowego na rozwój kultu i Drogi św. Jakuba, Wydawnictwo „Czuwajmy”, Kraków 2011, s. 118.

6. Jackowski A., Sołjan I., Pielgrzymki do Santiago de Compostela w czasie i przestrzeni, [w:] Jackowski A., Mróz F., Hodorowicz I. (red.), Drogi św. Jakuba w Polsce. Stan badań i organizacja, IGiGP UJ, PPWSZ w Nowym Targu, Bractwo św. Jakuba Starszego Apostoła Oddział Małopolski w Więcławicach Starych, Kraków 2008, s. 15-16.

7. Jackowski A., Turystyka religijna - problemy badawcze i terminologiczne... s. 237-238.

8. Jackowski, Turystyka religijna - problemy badawcze i terminologiczne, [w:] A. Jackowski, F. Mróz, I. Hodorowicz (red.), Turystyka religijna na obszarach górskich, Wyd. Podhalańska Państwowa Wyższa Szkoła Zawodowa w Nowym Targu, Nowy Targ 2009, s. 237-238.

9. Jędrysiak T. (red.), Turystyka kulturowa, Polskie Wydawnictwo Ekonomiczne, Warszawa 2008, s. 23

10. Mendyk E., F. Mróz, Droga Św. Jakuba w Polsce. Kalendarium wydarzeń w 1. 2004-2009 [w:] I. Hodorowicz, Mróz F. (red.), Pielgrzymi na Drodze Św. Jakuba, Przeszłość i Teraźniejszość, Wyd. Podhalańska Państwowa Wyższa Szkoła Zawodowa w Nowym Targu, Kraków 2009, p. 77-84.

11. Mendyk E., Mróz F., Mróz Ł., Droga Św. Jakuba w Polsce. Kalendarium wydarzeń w świętym roku Jakubowym [w:] Jackowski A., Hodorowicz I., Mróz F. (red.), Wpływ Świętego Roku Jakubowego na rozwój kultu i Drogi Św. Jakuba, Wyd. „Czuwajmy”, Kraków 2011, s. 163-175.

12. Mikos von Rohrscheidt A., Turystyka kulturowa. Fenomen, potencjał, perspektywy. Podręcznik akademicki, Wyd. Milenium, Gniezno 2008, s. 31.

13. Por. Wójtowicz M., Przekształcenia ruchu pielgrzymkowego do Santiago de Compostela w latach 1989-2010, „Peregrinus Cracoviensis”, 22, Kraków 2011, s. 317. 14. Roszak P., Homo peregrinus. Kim jest prawdziwy pielgrzym?, [w:] Roszak 

ISSN 2078-6441. Вісник Львівського університету. Серія географічна. 2013. Випуск 43. Ч. 2.

P. (red.), Camino de Santiago - nie tylko droga. Historia i współczesność Szlaku św. Jakuba, Wydawnictwo Naukowe Uniwersytetu Mikołaja Kopernika, Toruń 2012, s. 23.

15. Temperán E., Santiago de Compostela - miasto na końcu świata. Zarys historii katedry compostelańskiej, [w:] Roszak P. (red.), Camino de Santiago - nie tylko droga. Historia i współczesność Szlaku św. Jakuba, Wydawnictwo Naukowe Uniwersytetu Mikołaja Kopernika, Toruń 2012, s. 66-67.

16. The Holy Year of St. James (Ano Santo Jacobeo) is announced in Santiago de Compostela when the liturgical memorial of St. James the Apostle - 25 th July - falls on Sunday. The worshippers, who will visit the tomb of St. James, may obtain a jubilee indulgence. The Year of St. James falls every 6, 5,6 and 11 years. The last (119) Year of St. James was celebrated in 2010. The next Jubilee Year will be celebrated in 2021.

17. www.camino.net.pl/camino-europa/?page_id=18 [Retrieved: 07/01/2012].

18. www.de.wikipedia.org/wiki/Jakobsweg [Retrieved: 09/11/2012].

19. www.deutsche-jakobswege.de/vacha-fulda-wuerzburg.html [Retrieved: 07/15/2012].

20. www.elisabethpfad.de [Retrieved: 07/05/2012].

21. www.euroopera.org/via-regia [Retrieved : 10/01/2011

22. www.ewt.gov.pl/WstepDoFunduszyEuropejskich/Documents/ZABINSKI_VIA.pdf [Retrieved: $10 / 05 / 2011]$

23. www.jakobswege-marburg.de [pozyskano 5.07.2012 r.].

24. www.jakobusgesellschaft.eu/pilgern/wegbeschreibungen [Retrieved: 07/15/2012].

25. www.jakuby.eu [Retrieved : 10/01/2011]

26. www.oekumenischer-pilgerweg.de [Retrieved: 07/15/2012].

27. www.peregrinossantiago.es/esp/oficina-del-peregrino/estadisticas/ [Retrieved: 05/15/2012 ].

28. www.peregrinossantiago.es/esp/oficina-del-peregrino/estadisticas/?anio=2012\&mes $=7$, [Retrieved: 09/20/2012].

29. www.peregrinossantiago.es/esp/wp-content/uploads/informes/peregrinaciones2010.pdf Retrieved: $10 / 26 / 2012]$.

30. www.peregrinossantiago.es/esp/wp-content/uploads/informes/peregrinaciones2011.pdf Retrieved: 10/26/2012].

31. www.peregrinossantiago.es/esp/wp-content/uploads/informes/peregrinaciones2010.pdf [Retrieved: 10/26/2012].

32. www.peregrinossantiago.es/esp/wp-content/uploads/informes/peregrinaciones2011.pdf [Retrieved: 10/26/2012].

\begin{tabular}{l} 
33. www.szlakimalopolski.mik.krakow.pl/2010/11/09/via-regia-w-malopolsce/ [Retrieved: \\
\hline
\end{tabular} $10 / 10 / 2011]$

Стаття: надійшла до редколегії 25.05.2012

прийнята до друку 06.06.2012 


\title{
ПАЛОМНИЦТВО І РЕЛІГІЙНИЙ ТУРИЗМ ПО ШЛЯХУ СВ. ЯКОВА - ПЕРШИЙ ЄВРОПЕЙСЬКИЙ КУЛЬТУРНИЙ МАРШРУТ
}

\author{
Ф. Мруз *, Л. Мруз ** \\ * Педагогічний університет Кракова - Інститут Географії \\ Держава Подхальская Вища Професійно-технічна Школа в Новому Таргу \\ ** Університет Егілонскій в Кракові - Інститут Географії та Просторового \\ управління
}

3 минулих двох десятиліть ми помічаємо інтенсивне зростання руху паломництва по шляху Св. Якова. Цей маршрут, який з'єднує місця в Європі і закінчується в Сантьяго-деКомпостела, заснований на середньовічному маршруті пересування під назвою Королівський Маршрут. Маршрут існує більше 1000 років і постійно розвивається завдяки заходам, вжитим владою Католицької церкви, урядами та неурядовими організаціями, так само численними шанувальниками шляху Св. Якова.

Ключові слова: шлях Св. Якова - Каміно де Сантьяго, європейські Культурні Маршрути, паломництво, релігійний туризм, культурний туризм.

\section{ПАЛОМНИЧЕСТВО И РЕЛИГИОЗНЫЙ ТУРИЗМ ПО ПУТИ СВ. ЯКОВА}

\section{ПЕРВЫЙ ЕВРОПЕЙСКИЙ КУЛЬТУРНЫЙ МАРШРУТ}

\author{
Ф. Мруз*, Л. Мруз** \\ *Педагогический университет Кракова - Институт Географии \\ Государство Подхальская Высшая Профессионально-техническая Школа $в$ \\ Новом Тарге \\ **Университет Егилонский в Кракове - Институт Географии и \\ Пространственного управления
}

С прошлых двух десятилетий мы замечаем интенсивный рост движения паломничества по пути Св. Якова. Этот маршрут, соединяющий места в Европе и заканчивающийся в Сантьяго-де-Компостеле, основан на средневековом маршруте передвижения под названием Королевский Маршрут. Маршрут существует больше 1000 лет и постоянно развивается благодаря мерам, предпринятым властями Католической церкви, правительствами и неправительственными организациями, так же многочисленными поклонниками пути Св. Якова.

Ключевые слова: путь Св. Якова - Камино де Сантьяго, европейские Культурные Маршруты, паломничество, религиозный туризм, культурный туризм. 